\title{
Tectonics of the Himalaya: an introduction
}

\author{
SOUMYAJIT MUKHERJEE ${ }^{1 *}$, RODOLFO CAROSI ${ }^{2}$, PETER VAN DER BEEK ${ }^{3}$, \\ BARUN KUMAR MUKHERJEE ${ }^{4} \&$ DELORES M. ROBINSON ${ }^{5}$ \\ ${ }^{1}$ Department of Earth Sciences, Indian Institute of Technology Bombay, \\ Powai, Mumbai 400 076, Maharashtra, India \\ ${ }^{2}$ Dipartimento di Scienze della Terra, v. Valperga Caluso, 3510125 Torino, Italy \\ ${ }^{3}$ Université Grenoble Alpes, Institut des Sciences de la Terre, 38041 Grenoble, France \\ ${ }^{4}$ Petrology and Geochemistry Group, Wadia Institute of Himalayan Geology, \\ 33 GMS Road, Dehra Dun 248001, India \\ ${ }^{5}$ Department of Geological Sciences, University of Alabama, 201 7th Ave, \\ Room 2003 Bevill Building, Tuscaloosa, AL 35487, USA
}

*Corresponding author (e-mail: soumyajitm@gmail.com)

Studies of the spatial and temporal evolution of collisional orogens, such as the Himalaya, have been experiencing a revival over the past 15 years with the development of new geochronological, thermochronological and isotopic analytical techniques. These advanced techniques include Raman thermometry, $\mathrm{Sr}-\mathrm{Nd}-\mathrm{Hf}$ and $\varepsilon \mathrm{Nd}$ studies, ${ }^{40} \mathrm{Ar} /{ }^{39} \mathrm{Ar}$ and $\mathrm{U}-\mathrm{Th}-\mathrm{Pb}$ zircon dating. This volume, Tectonics of the Himalaya, explores and tests the most recent tectonic models from structural, metamorphic, geochemical, geochronological, geophysical and other perspectives.

This volume consists of 13 papers. Mathematical modelling of deep crustal flow within the Himalayan orogen leads Mandal et al. (2015) to propose that the three types of topography in the Himalaya depend primarily on the rate of underthrusting of the Indian plate, with the deep crustal flow type governing the observed topography. The authors consider a single homogeneous ductile material to represent the orogen devoid of a brittle upper layer, and point out the possibility of extending the model in $3 \mathrm{D}$ to take into account the regional curvature of the orogen and varying convergence rate of the Indian plate. Montomoli et al. (2014) review the tectonic and metamorphic discontinuities within the Greater Himalayan Crystallines and conclude that a top-to-the-SW ductile shear zone, called the High Himalayan Discontinuity, is a regional-scale feature that can be traced for several hundred kilometres along the orogenic strike. This tectonic feature accommodated the exhumation of the Greater Himalayan Crystallines during Oligocene time before activation of the Main Central Thrust. These authors prefer to classify the entire Greater Himalayan Crystallines into an upper and a lower part, with the High Himalayan Discontinuity defining the boundary between the two lithotectonic units.

Gupta \& Gahalaut (2015) review Himalayan earthquakes and argue against the possibility of a large $\left(\sim \mathrm{M}_{\mathrm{w}} 9\right)$ earthquake occurring because Himalayan deformation has been distributed on several in-sequence and out-of-sequence thrusts. However, the authors do not dismiss the possibility of future large earthquakes in the Himalaya with severe loss of life. In their review, the authors mention that the 2008 Kashmir earthquake indicates out-of-sequence thrusting. Density modelling by Tiwari et al. (2014) for the western Himalaya indicates local slab break-off in the deeply and steeply subducted Eurasian and Indian plates. In their study area in Ladakh-Karakoram-HindukushPamir, the authors decipher at a few locations gravity highs as upthrust blocks and gravity lows as downthrust units.

Mukherjee (2015) reviews out-of-sequence deformation from the Siwalik, Lesser Himalaya and Greater Himalayan Crystallines from Pakistan, India, Nepal and Bhutan. Thrusting seems to be more common than fracturing as an out-of-sequence deformation mechanism. Shortening related to out-of-sequence thrusting is usually insignificant compared with the shortening accommodated on Himalayan in-sequence thrusts. Out-of-sequence faults can also be back-thrusts, surface-breaking or blind faults, either strike slip or dominantly dip slip.

$\mathrm{U}-\mathrm{Th}-\mathrm{Pb}$ dating of monazite in kyanitebearing gneiss from the central Nepal Himalaya by Carosi $\boldsymbol{e t} \boldsymbol{a l}$. (2014) indicates that a tonalite melt was entrapped within the gneiss at 41-36 Ma in the kyanite stability field. They found that the 
Oligocene age melts are not limited to the South Tibetan Gneiss Domes, but also occur in the frontal part of the Himalayan belt, as well as in the Namche Barwa syntaxis. They also decipher a prolonged period of melting in the Himalaya during prograde metamorphism. Leloup et al. (2015) document the crystallization of in situ melts at $24-18 \mathrm{Ma}$ in Greater Himalayan Crystallines exposed in the Nyalam section of the central Himalaya, with the Greater Himalayan Crystallines undergoing rapid cooling. These authors propose a flat-and-ramp geometry for the overlying South Tibetan Detachment System. The authors do not consider the South Tibetan Detachment System to be a 'passive' structure, and therefore question the applicability of the channel flow model of deformation to the Greater Himalayan Crystallines.

Rolfo et al. (2014) review the $P-T-t$ paths from several transects across the Greater Himalayan Crystallines of eastern Nepal and, even allowing for the lack of geochronological constraints for the $P-T-t$ paths, conclude that the overall geometries are compatible with the channel flow model. The authors consider the observed metamorphic discontinuities within the Greater Himalayan Crystallines to be second-order features not significantly affecting the extrusion of hot channel material.

Martin et al. (2014) date Greater and Lesser Himalaya rocks from the southern part of the Annapurna Range (central Nepal) and attribute the young $\mathrm{Ar}-\mathrm{Ar}$ cooling ages to a frontal ramp and/or motion on a cross-cutting, northeast-trending fault. They infer the presence of a shear zone (the Bhanuwa fault) with a normal sense of motion. Khanal et al. (2014) present a study of the Ramgarh-Munsiari thrust sheet exposed in the Himalaya of central Nepal, in which they integrate field and microstructural observations, $\mathrm{Nd}$ isotopic data and $\mathrm{U}-\mathrm{Pb}$ zircon ages of igneous and metasedimentary rocks. The authors recognize that what has previously been referred to as the 'MCT zone' is actually composed of two thrust sheets. The northernmost thrust at the base of the Greater Himalayan Crystallines is the Main Central Thrust, with the RamgarhMunsiari thrust carrying Lesser Himalayan rocks in the footwall of the Main Central Thrust. Both thrust sheets are folded underneath the Kathmandu klippe. They considered the Ramgarh-Munsiari thrust sheet to extend much further along the orogenic strike than previously considered.

Mandal et al. (2014) detail geochemical studies from the Kumaon Himalaya of NW India, and determine that rocks carried in the Almora klippe may be geochemically correlated with the Greater Himalayan Crystallines exposed north of the Main Central Thrust. They therefore propose that the fault at the base of the Almora klippe is the Main Central Thrust. Another thrust carrying Paleoproterozoic rocks in the footwall of the Main Central Thrust and folded underneath the Almora klippe is correlated with the Ramgarh-Munsiari Thrust.

Das et al. (2015) postulate that the differentiation of primitive magma occurred during the thickening stage of the Himalayan belt. Within peridotitic rocks of the Nidar Ophiolite Complex (NW Himalaya), they report mineral phases sourced and transported via dunite channels from the mantle transition zone and suggest that the Nidar Ophiolite evolved from a mantle section located beneath a palaeo-mid-ocean ridge spreading centre. Zeng et al. (2014) decipher Mid-Eocene magmatism from the Yardoi Gneiss Dome in the Tethyan Himalaya (southern Tibet) based on zircon $\mathrm{U}-\mathrm{Th}-\mathrm{Pb}$ isotopic analyses and conclude that deep crustal rocks underwent early partial melting under crustal thickening conditions.

We thank all the authors and reviewers of the individual manuscripts submitted to this volume for their contributions. We also thank Matthew Kohn and an anonymous reviewer for constructive comments on our original book proposal. We are grateful to Georges Mascle, Arnauld Pêcher, Michel Colchen and Stéphane Guillot for writing the Patrick Le Fort memorial, to Yani Najman and Chris Talbot for making minor corrections, and to Franco Rolfo and Chiara Groppo for preparing the Bruno Lombardo memorial. Support from Angharad Hills, Sarah Gibbs, Tamzin Anderson and Jo Armstrong at the Geological Society of London Publishing House and Richard Law (GSL Chief Books Editor) is gratefully acknowledged. We pay tribute to the victims of the 2015 Nepal earthquake, and trust that continuing tectonic research on the Himalaya will, in the long run, result in societal benefits.

\section{References}

Carosi, R., Montomoli, C. ET AL. 2014. Eocene partial melting recorded in peritectic garnets from kyanite-gneiss, Greater Himalayan Sequence, central Nepal. In: MukherJeE, S., CARosi, R., VAN DER Beek, P. A., Mukherjee, B. K. \& Robinson, D. M. (eds) Tectonics of the Himalaya. Geological Society, London, Special Publications, 412. First published online September 9, 2014, http://doi.org/10.1144/ SP412.1

Das, S., Mukherjee, B. K., Basu, A. R. \& Sen, K., Jr., 2015. Peridotitic minerals of the Nidar Ophiolite in the NW Himalaya: sourced from the depth of the mantle transition zone and above. In: MuKherJeE, S., Carosi, R., van der Beek, P. A., Mukherjee, B. K. \& Robinson, D. M. (eds) Tectonics of the Himalaya. Geological Society, London, Special Publications, 412. First published online May 20, 2015, http://doi.org/10.1144/SP412.12

Gupta, H. K. \& Gahalaut, V. K. 2015. Can an earthquake of $\mathrm{M}_{\mathrm{w}} \sim 9$ occur in the Himalayan region? In: Mukherjee, S., Carosi, R., van der Beek, P. A., MukherJee, B. K. \& Robinson, D. M. (eds) Tectonics of the Himalaya. Geological Society, London, Special 
Publications, 412. First published online May 5, 2015, http://doi.org/10.1144/SP412.10

Khanal, S., Robinson, D. M., Mandal, S. \& Simkhada, P. 2014. Structural, geochronological and geochemical evidence for two distinct thrust sheets in the 'Main Central thrust zone', the Main Central thrust and Ramgarh-Munsiari thrust: implications for upper crustal shortening in central Nepal. In: MuKHERJEE, S., Carosi, R., van der Beek, P. A., Mukherjee, B. K. \& Robinson, D. M. (eds) Tectonics of the Himalaya. Geological Society, London, Special Publications, 412. First published online September 11, 2014, http://doi.org/10.1144/SP412.2

Leloup, P. H., Liu, X., Maheo, G., Paquette, J.-L., Arnaud, N., Aubray, A. \& LiU, X. 2015. New constraints on the timing of partial melting and deformation along the Nyalam section (central Himalaya): implications for extrusion models. In: MUKHERJEE, S., Carosi, R., van der BeeK, P. A., MukherJee, B. K. \& Robinson, D. M. (eds) Tectonics of the Himalaya. Geological Society, London, Special Publications, 412. First published online June 3, 2015, http://doi.org/10.1144/SP412.11

Mandal, N., Bose, S., Baruah, A. \& Sarkar, S. 2015. First-order topography of the Himalayan Mountain belt: a deep-crustal flow analysis. In: MukHERJEe, S., Carosi, R., van der BeeK, P. A., Mukherjee, B. K. \& Robinson, D. M. (eds) Tectonics of the Himalaya. Geological Society, London, Special Publications, 412. First published February 2, 2015, http://doi. org/10.1144/SP412.9

Mandal, S., Robinson, D. M., Khanal, S. \& Das, O. 2014. Redefining the tectonostratigraphic and structural architecture of the Almora klippe and the Ramgarh-Munsiari thrust sheet in NW India. In: Mukherjee, S., Carosi, R., van der Beek, P. A., MukherJee, B. K. \& Robinson, D. M. (eds) Tectonics of the Himalaya. Geological Society, London, Special Publications, 412. First published online September 17, 2014, http://doi.org/10.1144/SP412.6

Martin, A. J., Copeland, P. \& Benowitz, J. A. 2014. Muscovite ${ }^{40} \mathrm{Ar} /{ }^{39} \mathrm{Ar}$ ages help reveal the Neogene tectonic evolution of the southern Annapurna Range, central Nepal. In: MukherJeE, S., Carosi, R., vaN
Der BeeK, P. A., Mukherjee, B. K. \& Robinson, D. M. (eds) Tectonics of the Himalaya. Geological Society, London, Special Publications, 412. First published online September 25, 2014, http://doi.org/10. $1144 /$ SP412.5

Montomoli, C., Carosi, R. \& Iaccarino, S. 2014 Tectonometamorphic discontinuities in the Greater Himalayan Sequence: a local or a regional feature? In: Mukherjee, S., Carosi, R., van Der Beek, P. A., Mukherjee, B. K. \& Robinson, D. M. (eds) Tectonics of the Himalaya. Geological Society, London, Special Publications, 412. First published online September 18, 2014, http://doi.org/10.1144/SP412.3

MukHerJeE, S. 2015. A review on out-of-sequence deformation in the Himalaya. In: MukherJeE, S., CARosi, R., van der BeeK, P. A., MukherJee, B. K. \& RobiNson, D. M. (eds) Tectonics of the Himalaya. Geological Society, London, Special Publications, 412. First published online May 26, 2015, http://doi.org/10.1144/ SP412.13

Rolfo, F., Groppo, C. \& Mosca, P. 2014. Petrological constraints of the 'Channel Flow' model in eastern Nepal. In: MukherJee, S., Carosi, R., VAN DER Beek, P. A., Mukherjee, B. K. \& Robinson, D. M. (eds) Tectonics of the Himalaya. Geological Society, London, Special Publications, 412. First published online September 9, 2014, http://doi.org/10.1144/ SP412.4

Tiwari, V. M., Mishra, D. C. \& Pandey, A. K. 2014. The lithospheric density structure below the western Himalayan syntaxis: tectonic implications. In: MUKHERJEe, S., Carosi, R., van der BeeK, P. A., MukherJee, B. K. \& Robinson, D. M. (eds) Tectonics of the Himalaya. Geological Society, London, Special Publications, 412. First published online October 2, 2014 http://doi.org/10.1144/SP412.7

Zeng, L., GaO, L.-E., Tang, S., Hou, K., Guo, C. \& Hu, G. 2014. Eocene magmatism in the Tethyan Himalaya, southern Tibet. In: MukHerJee, S., CARosi, R., VAN Der BeeK, P. A., MukherJee, B. K. \& Robinson, D. M. (eds) Tectonics of the Himalaya. Geological Society, London, Special Publications, 412. First published online October 27, 2014, http://doi.org/10. $1144 /$ SP412.8 